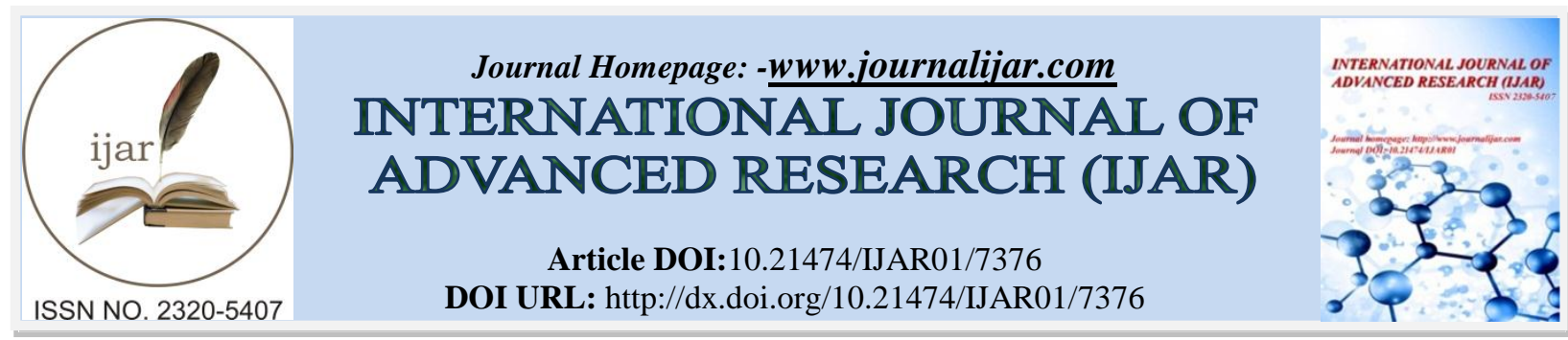

RESEARCH ARTICLE

\title{
ANTIFUNGAL ACTIVITY OF SOME MEDICINAL PLANTS EXTRACTS AGAINST THE PATHOGEN CAUSING PHOMOPSIS BLIGHT OF BRINJAL (SOLANUM MELONGENA L.).
}

Sabebaro Namo Das ${ }^{1}$, Dhananjay Das ${ }^{2}$ and T. C. Sarma ${ }^{3}$.

1. Department of Botany, B.P.Chaliha College, Nagarbera, Kamrup (R) Assam.

2. Department of Chemistry, Gauhati University, Guwahati-14.

3. Department of Botany, Gauhati University, Guwahati-14, Assam.

\section{Manuscript Info}

Manuscript History

Received: 09 May 2018

Final Accepted: 11 June 2018

Published: July 2018

Keywords:-

Brinjal, Phomopsis blight, Antifungal

plant, Aqueous extract.

\begin{abstract}
Brinjal or eggplant (Solanummelongena L.) is an important vegetable crop grown in Assam. Phomopsis blight or fruit rot disease of brinjal is one of the most devastating diseases of all brinjal growing field caused by Phomopsis vexans. In this context the present investigation has been undertaken with a view to studying in vitro efficacy of some antifungal plant extracts viz. bulb extracts of Allium sativum, leaf, roots and seeds extract of Ricinus communis and bark extracts of Terminalia arjuna against the mycelial growth of the pathogen. Among the tested plants, the aqueous extracts of $15 \%$ concentration of Allium sativum (100\%), seed extracts of Ricinus communis $(77.1 \%$ ) followed by root extracts $(55.5 \%)$, leaf extract $(53.8 \%)$ and bark extracts $(27.5 \%)$ inhibited the growth of the pathogen.
\end{abstract}

Copy Right, IJAR, 2018,. All rights reserved.

\section{Introduction:-}

The brinjal (Solanum melongena L.) belongs to the family 'Solanaceae' is one the most common, highly productive and popular vegetable crop grown globally and widely cultivated in India. It is a major source of income for the common farmers as well.

This important food crop is affected by various diseases which causes damage in all growth stage limiting production. The diseases are caused by fungi, bacteria, viruses, nematodes. Among them Phomopsis blight or fruit rot of brinjal caused by Phomopsis vexans. (Sacc. and Syd.) is a most devastating disease (Das, 1998; Khan, 1999). Under suitable weather conditions this disease may cause $12-25 \%$ loss in crop yield due to flower drop and fruit rot (Kannan et al., 1998). Phomopsis vexans causes over 50\% losses in production and productivity of brinjal in various parts of the world (Nolla, 1929). Phomopsis vexans causes fruit rot and leaf blight of brinjal and it reduces yield and marketable value of the crop nearly 20-30\% (Jain and Bhatnagar, 1980; Kaur et al., 1985). In Assam, it has been reported that the disease has been found to be most serious and widely distributed. The inappropriate use of agrochemicals especially fungicides were found to possess adverse effects on ecosystems and a possible carcinogenic risk than insecticides and herbicides together (Osman and AI-Rehiayam, 2003; Sive et.al. 2008). Moreover, resistance by pathogens to fungicides has rendered certain fungicides ineffective (Zhonghua and Michailides, 2005). Due to the aforementioned considerations, there may be a need to develop new management systems to reduce the dependence on the synthetic agrochemicals. Several higher plants and their constituents have been successful in plant disease control and have proved to be harmless and non-phytotoxic, unlike chemical

Corresponding Author:-SabebaroNamo Das.

Address:-Department of Botany, B.P.Chaliha College, Nagarbera, Kamrup (R) Assam. 
fungicides present study was taken some commonly available plant extracts were evaluate under laboratory condition against the pathogen.

\section{Materials and Methods:-}

The pathogen Phomopsis vexans isolated from the infected brinjal fruit collected from farmers' field of Goalpara district, Assam following tissue segmentation method. The pure culture was maintained in Potato Dextrose Agar slants at $4^{\circ} \pm 1^{\circ} \mathrm{C}$.

\section{Invitro bioassay of Phytoextracts:-}

Aqueous extracts of Allium sativum bulb and leaf, roots and seeds extracts of Ricinus communis and bark extracts of Terminalia arjuna were tested for their antifungal property against Phomopsis vexans by Poisoned Food Technique (Nene, 1971) under invitro condition. The test plants were taken for preparing crude extracts. They were thoroughly washed with water and fine slurry was prepared by taking $100 \mathrm{~g}$ with $100 \mathrm{ml}$ of distilled water $(1: 1 \mathrm{w} / \mathrm{v})$. The resultant slurry was filtered through muslin cloth and then through what man No. 1 filter paper and the extracts were used as stock solution. From the stock solution different concentration of aqueous extracts like $5 \mathrm{ml}, 10 \mathrm{ml}$ and 15 $\mathrm{ml}$ was added with $95 \mathrm{ml}, 90 \mathrm{ml}$ and $85 \mathrm{ml}$ of PDA media to make 5\%,10\% and 15\% concentrations respectively. The media was thoroughly shaken for uniform mixing of extracts. $20 \mathrm{ml}$ of media were poured into sterile petriplates. Mycelium of seven mm size discs from periphery of actively growing culture were cut out by sterile cork borer and one such disc was placed at the centre of each agar plate. Petriplates contain only pathogen on PDA media served as control. Percentage inhibition of radial growth by plant extracts was calculating using the formula: (Vincent, 1947)

$\mathrm{I}=\frac{\mathrm{C}-\mathrm{T}}{\mathrm{C}} \times 100$

Where, I = Percent inhibition over control

$\mathrm{C}=$ Radial growth in control

$\mathrm{T}=$ Radial growth in treatment

\section{Result and Discussion:-}

Result indicated that plant extracts could cause growth inhibition of test fungi, although the rate of inhibition of tested fungi varied with different extracts and concentrations. Among them bulb extracts of Allium sativum was found most effective (100\%) followed by seed extracts of Ricinus communis $(77.1 \%)$, root extracts $(55.5 \%)$ and leaf extracts (53.8\%). Least inhibition was observed with bark extracts of Terminalia arjuna (27.5\%). Table 1 . Fig. 1

All concentrations of the tested plants extracts were found to be inhibitory against the fungus and the rate of inhibition increased generally by increasing the concentration. The plant extracts at 15 percent concentration were significantly superior over the other two concentrations i.e. 10 and 5 percent. The findings are in agreement with that of Islam (2004) who found that 76-100\% inhibition of mycelial growth of Phomopsis vexans by garlic bulb. Aqueous extracts of Ricinus communis leaves was found most effective against Candida albicans (Khan and Yadav, 2011).

Table 1:-Effect of different concentration of aqueous extracts on mycelial growth of Phomopsis vexans.

\begin{tabular}{|l|l|l|l|l|l|}
\hline \multirow{2}{*}{$\begin{array}{l}\text { S.L } \\
\text { No. }\end{array}$} & \multirow{2}{*}{ Botanical extracts } & \multicolumn{3}{|l|}{ Percent inhibition of mycelia growth } & \multirow{2}{*}{ Mean \pm S E } \\
\cline { 3 - 5 } & & \multicolumn{3}{|c|}{ Concentration } \\
\cline { 3 - 5 } & & 5 & 10 & 15 & \\
\hline 1 & Allium sativum & 100 & 100 & 100 & $100 \pm .00$ \\
\hline 2 & Ricinus communis (leaf) & 46.6 & 47.8 & 53.8 & $49.4 \pm 2.22$ \\
\hline 3 & Ricinus communis (root) & 46.4 & 53.2 & 55.5 & $51.7 \pm 2.73$ \\
\hline 4 & Ricinus communis (seeds) & 61 & 71.7 & 77.1 & $69.93 \pm 4.73$ \\
\hline 5 & Terminalia arjuna & 13.2 & 21.1 & 27.5 & $20.60 \pm 4.13$ \\
\hline
\end{tabular}




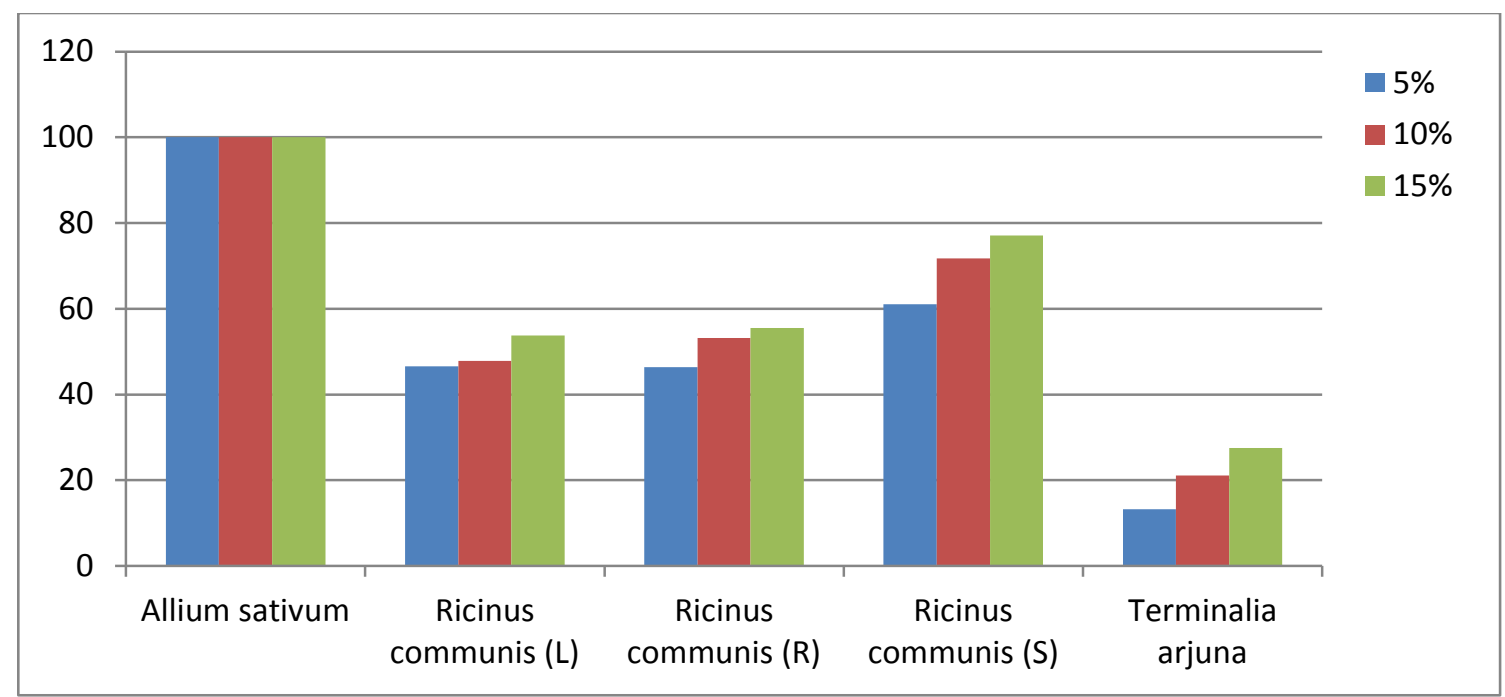

Fig. 1:-In vitro evaluation of plant extracts against Phomopsisvexans

\section{Conclusion:-}

Phomopsis fruit rot disease can cause severe losses in brinjal. It has been concluded from the present research that certain plant extracts are a source of cheap and effective fungicide against the pathogen Phomopsis vexans and they don't have human and environment health implications. So some plant extracts such as garlic and seed extract of Ricinus communis extract could be a good replacement for fungicides.

\section{Acknowledgement:-}

The authors are thankful to Principal for providing necessary laboratory facilities to pursue this research work.

\section{References:-}

1. Das BH (1998) Studies on Phomopsis fruit rot of brinjal. Msc Thesis, Department of plant pathology, Bangladesh Agricultural University, Mymensingh. Pp. 29-64.

2. Islam R (2004). Chromatographic separation of compounds in garlic bulb and Allamanda leaf extracts inhibitory to Phomopsis vexans. An M.Sc. Thesis submitted to the Department of plant pathology, Bangladesh Agricultural University, Mymensingh, Bangladesh. Pp. 23-26.

3. Jain MP and Bhatnagar MK (1980). Efficacy of certain chemicals in the control of fruit rots of brinjal. Pesticides. 14: 27-28.

4. Kannan R, Ananthan M and Balasubramani P (1998) Anthracnose a menace in chilli cultivation. Spice India. $11: 2-3$.

5. Kaur S, Kaur R, Kaur P and Singh D (1985). Studies on wilt and fruit rot of brinjal caused by Fusarium semitectum. Indian Phytopathology. 38:736-738.

6. Khan NU (1999). Studies on epidemiology, seed-borne nature and management of Phomopsis fruit rot of brinjal M.Sc. Thesis, Department of plant pathology Bangladesh Agricultural University, Mymensingh. Pp. 38-68.

7. Khan JA and Yadav KP (2011). Assessment of antifungal properties of Ricinus communis. Journal of Pharmaceutical and Biomedical Science. 11(2): 124-127.

8. Nene YL (1971). Fungicides in plant disease control. Oxford and IBH Publ. Co. New Delhi, pp. 386.

9. Nolla JAB (1929). The eggplant blight and fruit rot in Puerto Rico. Journal of the Department of Agriculture of Puerto Rico. 13:35-57.

10. Osman, KA and AI-Rehiayam S (2003). Risk assessment of pesticides to human and the environment. Saudi J. Biol. Sci, 10: 81-106.

11. Siva N, Ganesan S; Banumathy N and Mathuchelian N (2008). Antifungal effect of leaf extract of some medicinal plants against Fusarium oxysporum causing wilt disease of Solanum melongenaL. Ethnobot. 12: 156-163.

12. Zhonghua MA and Michailides TJ (2005). Advances in understanding molecular mechanisms of fungicidal resistance and molecular detection of resistant genotypes in phytopathogenic fungi. Cro Prot. 24:853-862.

13. Vincent JM (1947). Distortion of fungal hyphae in presence of certain inhibitors. Nature. 159:p.850. 